\title{
CORRELATION BETWEEN FATIGUE AND SELF-ESTEEM IN PATIENTS WITH MULTIPLE SCLEROSIS
}

\author{
Yára Dadalti Fragoso', Érika Oliveira da Silva², Alessandro Finkelsztejn ${ }^{3}$
}

\begin{abstract}
Objective: To assess the possible association of fatigue with self-esteem in multiple sclerosis (MS) patients. Method: Thirty patients were prospectively assessed. None of them presented moderate or severe depression or anxiety and their degree of disability was low (EDSS $\leq 3.5$ ). They had been clinically stable for at least three months and had been receiving the same medication for at least six months. Socioeconomic level was assessed. Severity of fatigue and self-esteem were evaluated using specific, validated scales. Patients with moderate to severe anxiety and/or depression were excluded. Results: Low self-esteem correlated with fatigue ( $p=0.01$ ), but not with any other variables, such as age, gender, EDSS, MS duration, number of relapses, mild depression and/or anxiety. Conclusion: Greater severity of fatigue in MS correlates with low self-esteem, thus suggesting that this chronic complaint that affects so many patients can interfere with the way in which they see and value themselves.
\end{abstract}

KEY WORDS: fatigue, self-esteem, depression, anxiety, multiple sclerosis.

\section{Correlação entre gravidade da fadiga e baixa estima na esclerose múltipla}

Resumo - Objetivo: Avaliar a possivel associação entre fadiga e autoestima em pacientes com esclerose múltipla (EM). Método: Trinta pacientes foram avaliados de forma prospectiva. Nenhum deles apresentava depressão ou ansiedade moderada ou grave, e o grau de incapacidade foi baixo (EDSS $\leq 3,5$ ). Eles estavam clinicamente estáveis por pelo menos três meses e estavam recebendo a mesma medicação por pelo menos seis meses. O nível socioeconômico foi avaliado. A gravidade da fadiga e a autoestima foram avaliadas pelo uso de escalas especificas e validadas. Pacientes com ansiedade e/ou depressão moderadas ou graves foram excluídos. Resultados: Baixa autoestima se mostrou correlacionada com fadiga ( $\mathrm{p}=0,01)$, porém não relacionada a qualquer outra variável, como sexo, idade, EDSS, duração da EM, número se surtos, depressão e/ou ansiedade leves. Conclusão: Maior gravidade de fadiga na EM se correlaciona com baixa autoestima, sugerindo assim que esta queixa crônica que afeta tantos pacientes pode interferir com a maneira pela qual eles se vêem e se valorizam.

PALAVRAS-CHAVE: fadiga, autoestima, depressão, ansiedade, esclerose múltipla.

Fatigue is a common and disabling symptom of multiple sclerosis (MS), and it frequently has a negative impact on quality of life'. This symptom is "invisible" to others, who may misunderstand the limitations imposed by such overwhelming feeling of tiredness ${ }^{2}$. Physical and mental fatigue do not seem to correlate with the degree of disability, or to cognitive decline ${ }^{3}$ and therefore such patients' chronic fatigue complaints may not be well understood by their relatives, work colleagues or caregivers. The underlying pathophysiological mechanisms for MS fatigue seem to include dysfunction of the basal ganglia and frontal cortex, as well as the chronic inflammatory condition ${ }^{4}$. There is no specific treatment for MS fatigue, and the few clinical trials on the subject have rendered rather frustrating results ${ }^{5-7}$. Non-pharmacological approaches include both rest ${ }^{8,9}$ and physical activity ${ }^{10-15}$. In short, there is no consensus on how to treat this frequent and disabling MS symptom. The difficulties involved in therapeutic approaches towards frequent and disabling conditions that are likely to be misunderstood and undervalued by others may influence such patients' behavior. Indeed, some studies show correlations between levels of depression and fa-

\footnotetext{
'Head of Neurology Department, Universidade Metropolitana de Santos, SP and Coordinator of the MS Center of the coastal region of the State of São Paulo, DRS IV, Santos SP, Brazil; ${ }^{2}$ Psychologist, Trainee at the MS Center of the coastal region of the State of São Paulo, DRS IV, Santos SP, Brazil; ${ }^{3}$ Neurologist, Hospital de Clínicas de Porto Alegre, Porto Alegre RS, Brazil.
} 
tigue $^{16}$, and both of these with alexithymia ${ }^{17}$. Our impression has been that, even for patients who are not chronically depressed and/or anxious, fatigue could alter the way in which they see themselves, thus subsequently affecting how they interact with others.

The objective of the present study was to assess the self-esteem of MS patients who suffer from fatigue.

\section{METHOD}

The project was approved by the Research Ethics Committee at UNIMES. Participation was voluntary and the evaluations were performed during regular consultations. Patients participating in this study signed a written consent statement. All patients were interviewed by the same psychologist (EOS) and clinically assessed by a single neurologist (YDF), and all data were sent blindly to another neurologist (AF) for analysis. This was a prospective study and no control group was assessed, since the parameters analyzed here were specific to the disease, i.e., fatigue in MS in relation to self-esteem. Due to the very high prevalence of fatigue among our MS patients, we could not provide a control group with MS and without some degree of fatigue.

MS was diagnosed according to the Mc Donald criteria, and all patients had been followed in our service for at least one year.

The exclusion criteria were related to other parameters that could influence self-esteem. In order to exclude any possible influence of disability, depression and/or anxiety on fatigue or self-esteem among these patients, all individuals who volunteered to participate in the study underwent specific assessments so that a more homogeneous group could subsequently be formed. Patients were enrolled only if they did not present moderate or severe depression and/or anxiety, according to the Hospital Anxiety and Depression Scale (HAD) ${ }^{18}$, as validated in Portuguese by Botega et al. ${ }^{19}$. Only patients with little or no disability were included, i.e. those who scored 3.5 points or less on the Expanded Disability Status Scale (EDSS) ${ }^{20}$. Patients were only included if they had received the diagnosis of MS for at least one year, and not presented a relapse for at least three months prior to the evaluation. Only patients who had not undergone medication changes within the previous six months were enrolled.

Socioeconomic level was assessed in accordance with Brazilian standards $\mathrm{s}^{21}$, taking into consideration schooling and house goods. The different levels were classified as A, B, C, D, E (highest to lowest) and 1 or 2 (higher or lower) within the previous social classes A, B or C.

The Portuguese version ${ }^{22}$ of the severity of fatigue scale ${ }^{23}$ was used to assess and grade fatigue.

Self-esteem was assessed using the Rosemberg Self-Esteem Scale (SES) $)^{24,25}$, as validated for use in Brazil ${ }^{26-28}$. This scale is widely used in over 50 countries, and has shown high reliability and validity. Briefly, higher score values show lower self-esteem. Scores of more than 15 points denote low self-esteem.
The scale's final score was used individually for each patient and the obtained number was analyzed in relation to other studied parameters.

The t-test was used to analyze continuous data and the chisquare test, for categorical data. Multiple linear regression was used to analyze different variables that could jointly influence the main outcome (self-esteem). Correlations were assessed using the Pearson and Spearman tests. Results were considered significant when $p<0.05$.

\section{RESULTS}

Thirty patients presenting relapsing-remitting MS according to the Mc Donald criteria were included in this study. The group consisted of nine males and 21 females, aged between 20 and 63 years (mean age $=42.7$ years \pm 11.78 ), with an average of 9 years since their MS was first diagnosed (range: 1 to 20 years). There were no significant differences between male and female patients regarding any of the clinical characteristics assessed in this study. Twenty patients were regularly using glatiramer acetate and ten patients were regularly using beta-interferon.

Patients' socioeconomic level included all categories, with no particular predominance of any of them, regarding schooling and the possession of house goods.

The average EDSS was $2.2 \pm 1.41$ and the mean number of relapses since diagnosis was $4.6 \pm 3.86$. Higher EDSS values were correlated with age $(p=0.026)$ and duration of MS $(p=0.024)$. Neither EDSS nor the number of relapses correlated with age, gender, mild anxiety, mild depression, fatigue or self-esteem.

None of these patients presented moderate or severe anxiety/depression. There were five mild cases of depression, which were undergoing treatment with low doses of fluoxetine or sertraline. The average score for anxiety was 7.1, while the average score for depression was 5.2; both of these were typical of normal scores. Higher scores for these mild conditions of anxiety and depression were not correlated with EDSS, duration of MS, age, gender, number of relapses, socioeconomic level or self-esteem.

The average score on the self-esteem scale was 7.3 \pm 3.8 . Whether analyzed individually or by multiple regression, there was no correlation between low self-esteem and depression, anxiety, EDSS, age, gender, socioeconomic level, time elapsed since MS diagnosis and number of relapses. There was a correlation between self-esteem and fatigue (Spearman coefficient $0.64 ; p=0.01$ ).

\section{DISCUSSION}

Self-esteem is defined as the individual's sense of his or her value or worth, or the extent to which a person values, approves of, appreciates, prizes or likes himself or herself ${ }^{29}$. It is a difficult concept for others to understand and there are few scales for its measurement. Most stud- 
ies use the Rosemberg scale ${ }^{24}$, although its scores tend to be skewed toward high self-esteem ${ }^{29}$. Therefore, it can be assumed that, when this scale shows low self-esteem, this is most likely to be really the case and it is not a biased result.

A variety of diseases, addictions and socioeconomic conditions may interfere with self-esteem ${ }^{30}$. Depression and anxiety could have influenced the results of the present study, but the patient selection excluded these variables. Even the low depression and anxiety scores among patients undergoing the present evaluation could not be correlated with low self-esteem. The condition of having a chronic and disabling illness did not seem to influence the self-esteem of the patients enrolled in this study. A study with a similar age and gender population, but without chronic diseases also showed similar results ${ }^{31}$. The degree of disability correlated with the duration of the disease, but neither of these could be correlated with low self-esteem.

Gender and age did not correlate with self-esteem, although some studies tend to show lower self-esteem among women ${ }^{32}$. There are few and conflicting results regarding socioeconomic level and self-esteem but, on the whole, these two variables seem to correlate ${ }^{33}$. However, the present study did not confirm this correlation, and both of these variables were independent.

The hypothesis for the present study was that fatigue in MS patients might correlate with low self-esteem. There are only very few studies on self-esteem and chronic fatigue syndrome ${ }^{34}$ and there are no studies on MS fatigue and self-esteem. Other scales for fatigue assessment have now been validated in Portuguese $e^{35}$, but the aim of the present study was to investigate the severity of fatigue. Therefore, the most appropriate scale for this evaluation was chosen for this study.

Although quality of life, depression, anxiety, cognition and disability are frequently evaluated in MS patients, self-esteem is an important aspect of life that is forgotten in such evaluations. The present study suggests that there may be a correlation between self-esteem and fatigue in MS patients. Only three out of the thirty patients assessed in the present study were undergoing psychotherapy, and none of them talked about self-esteem with the therapist. In fact, it was only after the results from this study that our MS center started to routinely question patients regarding their self-esteem.

\section{REFERENCES}

1. Hadjimichael O, Vollmer T, Oleen-Burkey M. Fatigue characteristics in multiple sclerosis: N Am Res Committee on Multiple Sclerosis. Health Qual Life Outcomes 2008;6:10.

2. Flesner G, Ek AC, Landtblom AM, Soderhamm O. Fatigue in relation to perceived health: people with multiple sclerosis compared with people in the general population. Scand J Caring Sci 2008;22:391-400.
3. Ytterberg C, Johansson S, Andersson M, Widen Holmqvist L, Von Koch L. Variations in functioning and disability in multiple sclerosis. J Neurol 2008;255:1432-1459.

4. Leocani L, Colombo B, Comi G. Physiopathology of fatigue in multiple sclerosis. Neurol Sci 2008;29(Suppl 2):S241-S243.

5. Pucci E, Branas P, D'Amico R, Giuliani G, Solari A, Taus C. Amantadine for fatigue in multiple sclerosis. Cochrane Database Syst Rev 2007;1:CD002818.

6. Tomassini V, Pozzilli C, Onesti E, et al. Comparison of the effects of acetyl L-carnitine and amantadine for the treatment of fatigue in multiple sclerosis: results of a pilot, randomised, double-blind, crossover trial. J Neurol Sci 2004;218:103-108

7. Stankoff B, Waubant E, Confavreux C, et al. Modafinil for fatigue in MS: a randomized placebo-controlled double-blind study. Neurology 2005;64:1139-1143.

8. Finlayson M. Pilot study of an energy conservation education program delivered by telephone conference call to people with multiple sclerosis. NeuroRehabilitation 2005;20:267-277.

9. Mathiowetz VG, Finalyson ML, Matuska KM, Chen HY, Luo P. Randomized clinical trial of an energy conservation course for people with multiple sclerosis. Mult Scler 2005;11:592-601.

10. Dodd KJ, Taylor NF, Denisenko S, Prasad D. A quantitative analysis of a progressive resistance exercise programme for people with multiple sclerosis. Disabil Rehabil 2006;28:1127-1134.

11. Navipour H, Madani H, Mohebbi MR, Navipour R, Roozbayani P, Paydar A. Improved fatigue in individuals with multiple sclerosis after participating in a short-term self care program. Neurorehabilitation 2006;21:37-41.

12. Van den Berg M, Dawes H, Wade DT et al. Treadmill training for individuals with multiple sclerosis: a pilot randomised trial. J Neurol Neurosurg Psychiatry 2006;77:531-533.

13. Kileff J, Ashburn A. A pilot study of the effect of aerobic exercise on people with moderate disability multiple sclerosis. Clin Rehabil 2005;19:165-169.

14. White LJ, McCoy SC, Castellano V, et al. Resistance training improves strength and functional capacity in persons with multiple sclerosis. Mult Scler 2004;10:668-674.

15. Fragoso YD, Santana DLB, Pinto RC. The positive effects of a physical activity program for multiple sclerosis patients with fatigue. NeuroRehabilitation 2008;23:153-157.

16. Beiske AG, Svensson E, Sandanger I, et al. Depression and anxiety amongst multiple sclerosis patients. Eur J Neurol 2008;15:239-245.

17. Bodini B, Mandarelli G, Tomasini V, et al. Alexithymia in multiple sclerosis: relationship with fatigue and depression. Acta Neurol Scand 2008;118:18-23.

18. Zigmond AS, Snaith RP. The hospital anxiety and depression scale. Acta Psych Scand 1983;67:361-370.

19. Botega, NJ, Bio MR, Zomignani MA, Garcia C Jr, Pereira, M. Transtornos de humor em enfermaria de clínica médica e validação da escala de medida (HAD) de ansiedade e depressão. Rev Saúde Pública 1995;29:355-363.

20. Kurtzke JF. Rating neurologic impairment in multiple sclerosis: an expanded disability status scale (EDSS). Neurology 1983;33:1444-1452.

21. ABEP - Associação Brasileira de Empresas de Pesquisa 2008; available at www.abep.org, data based upon 2005 results, last accessed in March, $5^{\text {th }}, 2009$.

22. Mendes MF, Tilbery CP, Felipe E. Fatigue and multiple sclerosis: preliminary study of 15 patients with self-reported scales. Arq Neuropsiquiatr 2000;58:467-470.

23. Krupp LB, LaRocca NG, Muir-Nash J, Steinberg AD. The fatigue severity scale: application to patients with multiple sclerosis and systemic lupus erythematosus. Arch Neurol 1989;46:1121-1123.

24. Rosenberg, M. Society and the adolescent self-image. Princeton, NJ: Princeton University Press, 1965.

25. Robins, RW, HM. Trzesniewski, KH. Measuring global self-esteem: construct validation of a single-item measure and the Rosemberg Self-Esteem Scale. Person Social Psychol Bull 2001;27:151-161.

26. Dini GM. Tradução para a língua portuguesa, adaptação cultural e validação do questionário de auto-estima de Rosenberg. Dissertação de 
Mestrado em Cirurgia Plástica Reparadora - Universidade Federal de São Paulo. Escola Paulista de Medicina. São Paulo, 2004.

27. Dini GM. Validade de construção e sensibilidade da escala de auto-estima Rosemberg/UNIFESP-EPM em lipoaspiração. Tese de Doutorado em Cirurgia Plástica Reparadora - Universidade Federal de São Paulo. Escola Paulista de Medicina. São Paulo, 2004.

28. Dini GM, Ferreira LM, Quaresma MR . Translation into Portuguese, cultural adaptation and validation of the Rosenberg self-esteem scale. Rev Soc Brasil Cirurg Plást 2004;19:41-52.

29. Blascovich J, Tomaka J. Measures of self-esteem. In: Robinson JP, Shaver PR, Wrightsman LS (Eds). Measures of personality and social psychological attitudes, Volume I. San Diego, CA: Academic Press, 1991.

30. Abood DA, Conway TL. Health value and self-esteem as predictors of wellness behavior. Health Values 1992;16:20-26.
31. Carvalho MIB. The Rosemberg/UNIFESP-EPM self-esteem scale of the Fundação de Ensino Superior do Vale do Sapucaí in Pouso Alegre. Tese de Mestrado Interinstitucional - UNIFESP/UNIVÁS. São Paulo/Pouso Alegre. Minas Gerais, 2006.

32. Twenge JM, Kampbell WK. Self-esteem and socioeconomic status: a meta-analytic review. Person Social Psychol Rev 2002;6:59-71.

33. Creswell C, Chalder T. Underlying self-esteem in chronic fatigue syndrome. J Psychosom Res 2002;53:755-761.

34. Belenky MF, Blythe MC, Goldberger NR, Tarule JM. Women's ways of knowing: the development of self, voice, and mind. New York: Basic Books, 1986.

35. Pavan K, Schmidt K, Marangoni B, Mendes MF, Tilbery CP, Lianza S. Multiple sclerosis: cross-cultural adaptation and validation of the modified fatigue impact scale. Arq Neuropsiquiatr 2007;65:669-673. 